\title{
AMERICAN GULTURE AND SOCIETY SINCE THE 1930s
}




\section{The Contemporary United States}

Series Editors: GHRISTOPHER BROOKEMAN AND WILlitam ISSEI.

PUBLISHED TITLES

Manning Marable

RACE, REFORM AND REBELLION: THE SECOND RECONSTRUCTION IN BLACK AMERICA, 1945-1982

Leonard Quart and Albert Auster

AMERICAN FILM AND SOCIETY SINCE 1945

Christopher Brookeman

AMERICAN GULTURE AND SOCIETY SINCE THE 1930s

FORTHCO:MING TITLES

William Issel

AMERICAN SOCIETY SINCE 1945

Kenneth Fox

METROPOLITAN AMERICA: URBAN LIFE IN THE UNITED STATES, 1945-1980

Rochelle Gatlin

AMERICAN WOMEN SINCE 1945

Philip Davies

AMERICAN GOVERNMENT AND POLITICS

Michael Dunne

AMERICAN FOREIGN RELATIONS SINCE THE SEGOND WORLD WAR

Sam Rosenberg

AMERICAN ECONOMIC DEVELOPMENT SINCE 1945 


\section{AMERICAN GULTURE AND SOGIETY SINGE THE 1930s}

Christopher Brookeman

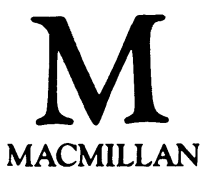




\author{
(C) Christopher Brookeman 1984 \\ Softcover reprint of the hardcover 1st edition 1984 \\ All rights reserved. No part of this pullication \\ may be reproduced or transmitted, in any form \\ or hy any means, without permission \\ First published 1984 by \\ Higher and Further Education Division \\ MACMILLAN PUBILISHERS LITD \\ London and Basingstoke \\ Companies and representatives \\ throughout the world \\ Typeset by \\ Wessex Typesetters I.td \\ Frome, Somerset
}

British L ibrary Cataloguing in Publication Data

Brookeman, Christopher

American culture and society since the

1930s.-Contemporary United States)

1. United States-Civilization-1918-1945

2. United States-Civilization-1945-

I. Title II. Series

973.8 E169.1

ISBN 978-0-333-29414-7 ISBN 978-1-349-17567-3 (eBook)

DOI 10.1007/978-1-349-17567-3 
To Hazel 


\section{Contents}

List of Plates $\quad$ ix

Preface xi

Editors' Preface xiii

Abbreviations $\quad$ xiv

1 THE LEGACY OF THE THIRTIES 1

2 DANIEL BELL AND THE CULTURAL CONTRADICTIONS OF CAPITALISM 8

3 THE FOUNDATIONS OF ANGLO-AMERICAN LITERARY THEORY

4 FROM SOUTHERN AGRARIANISM TO CRITICISM, INC. 24

5 THE DEBATE ON MASS CULTURE 41

6 ROBERT WARSHOW AND THE LEGACY OF THE 1930s

7 T. S. ELIOT AND MASS SOCIETY 67

8 THE FRANKFURT SCHOOL: MARXISM, FASCISM AND MASS CULTURE

9 HERBERT MARCUSE: FROM AFFIRMATION TO LIBERATION 
viii CONTENTS

10 THE LONELY CROWD: DAVID RIESMAN AND AMERICAN SOCIETY

11 MARSHALL MCLUHAN: THE MODERNISM OF THE MASS MEDIA

12 TOM WOLFE AND THE NEW JOURNALISM

13 NORMAN MAILER AND MASS AMERICA

14 COMING TO TERMS WITH HOLLYWOOD: FROM MASS TO AUTEUR THEORY

15 THE POLITICS AND AESTHETICS OF MODERNISM

16 SUSAN SONTAG: AGAINST INTERPRETATION 203

Notes

Selected Bibliography

Index 


\section{List of Plates}

1. Still from The Man Who Shot Liberty Valance, 1962, directed by John Ford. (C) Paramount Pictures

2. Immigrants Arriving at Ellis Island, 1937-38, detail of mural by Ben Shahn. For former Community Centre of Jersey Homesteads, Roosevelt, New Jersey. (c) Estate of Ben Shahn, 1981

3. Jackson Pollock at Work, 1951. (c) Hans Namuth

4. Going Westward, oil, c. 1934-38, by Jackson Pollock. By courtesy of the National Museum of American Art (formerly National Collection of Fine Arts), Smithsonian Institution. Gift of Thomas Hart Benton

5. Isaiah by Michelangelo. Detail from the Sistine Chapel

6. Rosie The Riveter by Norman Rockwell. Saturday Evening Post cover, 29 May 1943. Printed by permission of the Estate of Norman Rockwell. Copyright (C) 1943 Estate of Norman Rockwell

7. Front of the Solomon Guggenheim Museum, New York. (c) Ben Asen, 1984

8. Floyd Burroughs, Southern Share Cropper by Walker Evans, 1936. By courtesy of the Library of Congress

9. A Jewish Giant at Home with his Parents in the Bronx, New York, 1970 by Diane Arbus

Every effort has been made to trace all the copyright holders, but if any have been inadvertently overlooked the publishers will be pleased to make the necessary arrangement at the first opportunity. 


\section{Preface}

ANY survey of American culture since the 1930s is faced with the major problem of doing justice to an enormous range of activity in the American arts. The contribution this book seeks to make is to place selected developments in literary criticism, cultural theory and artistic practice within an historical context in order to provide a framework of analysis for students embarking on a study of contemporary American culture. The various uses to which the term culture is put in the book need some elaboration. Raymond Williams in Keywords (Fontana, 1976) has enumerated the various definitions and uses of the term. What this book aims to do is provide definitions within the context of the particular critic under review. Therefore for an art critic such as Clement Greenberg the culture of modernism functions as a shorthand way of evoking an experimental abstract tradition in painting that includes Cézanne, Picasso, Jackson Pollock and the other New York school of painters of the late 1940s and 1950s. For an anthropologist such as Margaret Mead the culture concept casts a much wider net of meaning than Clement Greenberg's arts-based tradition of abstract experimentation. One of the purposes of the book is to show how variously the term has been used by the critics whose ideas of culture are under review. Two important critiques of American culture, the feminist and the Afro-American, will be dealt with in other books of this series and therefore do not appear in this book.

I am indebted to the Polytechnic of Central London for a period of study leave to complete this book and to the many students and colleagues in both England and the United States with whom many of the ideas in the book were discussed and clarified. Thanks are also due to Chris Fowler and Marian Gleason who typed the manuscript.

C.B. 


\section{Editors' Preface}

Mention the United States and few people respond with feelings of neutrality. Discussions about the role of the United States in the contemporary world typically evoke a sense of admiration or a shudder of dislike. Pundits and politicians alike make sweeping references to attributes of modern society deemed 'characteristically American'. Yet qualifications are in order, especially regarding the distinctiveness of American society and the uniqueness of American culture. True, American society has been shaped by the size of the country, the migratory habits of the people and the federal system of government. Certainly, American culture cannot be understood apart from its multi-cultural character, its irreverence for tradition and its worship of technological imagery. It is equally true, however, that life in the United States has been profoundly shaped by the dynamics of American capitalism and by the penetration of capitalist market imperatives into all aspects of daily life.

The series is designed to take advantage of the growth of specialised research about post-war America in order to foster understanding of the period as a whole as well as to offer a critical assessment of the leading developments of the post-war years. Coming to terms with the United States since 1945 requires a willingness to accept complexity and ambiguity, for the history encompasses conflict as well as consensus, hope as well as despair, progress as well as stagnation. Each book in the series offers an interpretation designed to spark discussion rather than a definitive account intended to close debate. The series as a whole is meant to offer students, teachers and the general public fresh perspectives and new insights about the contemporary United States. 


\section{Abbreviations}

The following abbreviations are used for books frequently cited in the text.

DE Theodor Adorno and Max Horkheimer, Dialectic of Enlightenment (1944/1979)

SJ Daniel Bell, Sociological Journeys: Essays 1960-1980 (1980)

CCC The Cultural Contradictions of Capitalism $(1976 / 1979)$

SE T. S. Eliot, Selected Essays (1976)

ASG After Strange Gods: A Primer of Modern Heresy

NTDC Notes Towards the Definition of Culture (1948/1979)

CD Sigmund Freud, Civilization and its Discontents (1930/1979)

$A C \quad$ Clement Greenberg, Art and Culture (1961)

LPCS Leo Lowenthal, Literature, Popular Culture and Society (1968)

AAG Dwight Macdonald, Against the American Grain (1963)

OM On Movies (1981)

UM Marshall Mcluhan, Understanding Media: The Extensions of Man (1964/69)

PP Norman Mailer, The Presidential Papers (1976)

AN The Armies of the Night: History as a Novel, The Novel as History (1968)

EC Herbert Marcuse, Eros and Civilization (1955/1974)

EL An Essay on Liberation (1969)

GWT John Crowe Ransom, God Without Thunder: An Unorthodox Defence of Orthodoxy (1931)

$W B$

The World's Body (1938)

PC I. A. Richards, Practical Criticism: A Study of Literary Judgement (1929)

LC David Riesman, The Lonely Crowd: A Study of the Changing American Character (1950/1970) 
OP Susan Sontag, On Photography (1980)

LD Lionel Trilling, The Last Decade: Essays and Reviews, 1965-75 (1979)

$O S$ The Opposing Self: Nine Essays in Criticism $(1955 / 1980)$

IE Robert Warshow, The Immediate Experience: Movies, Comics, Theatre and other Aspects of Popular Culture $(1962,1971)$

NJ Tom Wolfe, The New Journalism (1975) 